University for Business and Technology in Kosovo

UBT Knowledge Center

Oct 27th, 9:00 AM - 10:30 AM

\title{
Urban Sprawl and its impact on Economic, Social and Environmental factors qStudy case -Suburban Neighborhood of Pristina (International Village, Neighborhood Qershia, Swiss Village)
}

Fjolla Abazi

University for Business and Technology, fa31474@ubt-uni.net

Elvida Pallaska

University for Business and Technology, elvida.pallaska@ubt-uni.net

Follow this and additional works at: https://knowledgecenter.ubt-uni.net/conference

Part of the Architecture Commons

\section{Recommended Citation}

Abazi, Fjolla and Pallaska, Elvida, "Urban Sprawl and its impact on Economic, Social and Environmental factors qStudy case -Suburban Neighborhood of Pristina (International Village, Neighborhood Qershia, Swiss Village)" (2018). UBT International Conference. 33.

https://knowledgecenter.ubt-uni.net/conference/2018/all-events/33

This Event is brought to you for free and open access by the Publication and Journals at UBT Knowledge Center. It has been accepted for inclusion in UBT International Conference by an authorized administrator of UBT Knowledge Center. For more information, please contact knowledge.center@ubt-uni.net. 


\title{
Urban Sprawl and its impact on Economic, Social and Environmental factors Study case -Suburban Neighborhood of Pristina (International Village, Neighborhood Qershia, Swiss Village)
}

\author{
${\text { Fjolla Abazi }{ }^{1} \text {, Elvida Pallaska }}^{2}$ \\ UBT - Higher Education Institution, Lagjja Kalabria, 10000 p.n., Prishtine, \\ Kosovo \\ fa31474@ubt-uni.net, elvida.pallaska@ubt-uni.net
}

\begin{abstract}
The impact of Urban Sprawl in economic, social and environmental factors is the subject to this research paper. Measurement of Urban Sprawl in cadastral zone Caglavica is one of the main objectives of this research

Based on data provided by the Kosovo Agency of Statistics regarding the increase of the number of collective residence in Prishtina, based on cartographies that show how Pristina was in the prewar period and how it was extended today, the cartographies that were presented in Pristina's municipal development plan, we understand that Pristina has increased in recent years by the number of constructions. Also based on the statistics of the Central Bank for Economic Development, we understand that Pristina has undergone a very rapid economic development. According to many scholars, the rapid development of cities influences their expansion. This expansion may be in some form and be caused by many factors, and some of these forms may have evidence of the country where one of them is urban sprawl.

By this paper research would be identified and weighted main indicators which are causing the urban sprawl in Prishtina municipality.
\end{abstract}

Keywords: Urban Sprawl, The impact of urban sprawl, Economic factors, Social factors, Environmental factors

\section{Introduction}

Based on data provided by the Kosovo Agency of Statistics regarding the increase of the number of collective residence in Prishtina, based on cartographies that show how Pristina was in the prewar period and how it was extended today, the cartographies that were presented in Pristina's municipal development plan, we understand that Pristina has increased in recent years by the number of constructions. Also based on the statistics of the Central Bank for Economic Development, we understand that Pristina has undergone a very rapid economic development. 


\section{Research purpose}

The purpose of the research is to study that neighborhoods in cadastral zone Çagllavica respectively International Village, Lagjja Qershia and Swiss Village belong to the bad urban layout. Learn the causes of urbanization quickly, low-dwelling of the type distributed in cadastral zone Caglavica. Also, the impacts of expanding these neighborhoods to land use, air quality and spending of natural resources, as well as to know how much the satisfaction, the well-being of residents or users of these neighborhoods is.

\section{Types of urban sprawl}

For a long time scholars have researched and analyzed the way urban layout, its nature and growth. From these analyzes it is understood that urban extension refers to the expansion of urban areas as a result of uncontrolled, uncoordinated and unplanned growth. Over the years, different research has made different denominations of forms of urban sprawl. A categorization of urban layout by two analysts of this problem Harvey and Clark (1971) is that the urban reach lies in three basic spatial forms such as: 1) Scattered development- uncordinated, 2) Strip develop, corridors of high accessibility along roads, and 3) Continuous expansion of low density (Barnes et al., 2000).

\section{Development of Building Construction}

Urban development of the city of Prishtina has been defined in the last 5 decades, where different urban planning plans began. But if we make a comparison of the spatial planning documents, the spatial plan that is in force today has expanded the boundaries of the urban area compared to the first spatial plan that was worked in 1986. Each city aims to preserve its identity, but Pristina with the unplanned and rapid development that has been in recent years, with the redesigning and incorrect restoration of historic buildings has greatly influenced the loss of identity, risking the city losing its identity.

According to Krasniqi (2011), the three main factors that have affected this urban condition are:

- Strategy planning using zoning as a planning tool and disrespect to the existing situation,

- The partial implementation of these projects and the other

- Lack of control of spontaneous constructions that have profoundly affected the physical and physical condition

- The aspect of urban urbanization
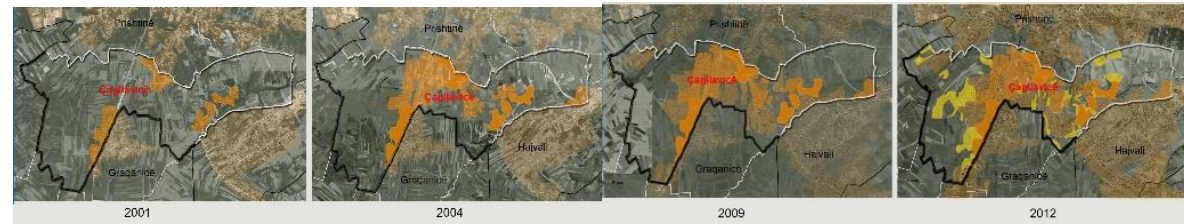

Fig. 4 Development of buildings in cadastral zone Cagllavica over the years

\section{Case study}

For the study, new residential quarters were built that were built in recent years in this cadastral zone. These neighborhoods are located in distance from each other. The International Village is located to the east of Cadastral Zone Çagllavicë which is connected by secondary roads with main roads, the International Village is limited to the north by the cadastral zone Matiqan whereas 
in the south, east and west it is limited by the area of the zone Cadastral Cagllavica, areas covered with low individual housing, as well as areas of agricultural land that are not being cultivated. While the other two neighborhoods, such as Swiss Village and Cherry, are located in the eastern part of Caglavica.

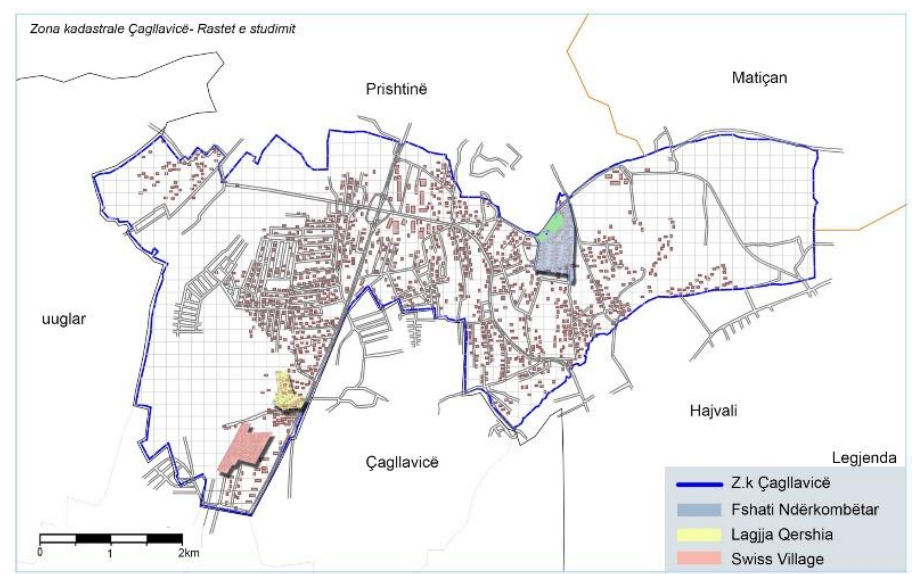

Fig. 6 Geographical position

\section{Analysis}

\section{Measurment of urban sprawl in Cagllavica zone}

To determine whether neighborhoods in cadastral zone Caglavica represent urban stretches, or not, WUP will be used in this research (Urban Wonder Distribution (WUP) method is the metric used in this study to determine the extent of urban alignment in each unit reporting is a DIS product, a weight of DIS, percentage of built-up area (PBA) in the reporting unit, and a weight of LUP, measured in UPU per square meter (UPU / m2). The range of values of WUP depends on the degree of analysis, which is determined by the perception horizon (HP)). The method that is explained in the literature review chapter.

Tab. 4 Categories of sprawl level

\begin{tabular}{|c|c|}
\hline \multicolumn{2}{|c|}{ Six categories of sprawl level } \\
\hline Unit & Categories \\
\hline$<1 \mathrm{UPU} / \mathrm{m}^{2}$ & Areas that are not sprawled \\
\hline 1-2 UPU / m² & Areas that are slightly sprawled \\
\hline 2-4 UPU / m² & Intermediate levels of sprawl \\
\hline 4-6 UPU / m² & Areas that are highly sprawled \\
\hline 6-9 UPU / m² & Very high levels of sprawl \\
\hline$>9 \mathrm{UPU} / \mathrm{m}^{2}$ & Extremely high levels or sprawl \\
\hline
\end{tabular}

Tab. 5 Parameters of urban sprawl 


\begin{tabular}{|c|c|c|c|c|}
\hline $\begin{array}{l}\text { Acronym } \\
\text { of the } \\
\text { metric }\end{array}$ & Name of the metric & Unit & $\begin{array}{l}\text { Range of low } \\
\text { values }\end{array}$ & $\begin{array}{l}\text { Range of } \\
\text { high values }\end{array}$ \\
\hline WUP & $\begin{array}{l}\text { Weight urban } \\
\text { proliferation }\end{array}$ & $\begin{array}{l}\text { UPU per } \mathrm{m}^{2} \text { of } \\
\text { landscape }\end{array}$ & $<2 \mathrm{UPU} / \mathrm{m}^{2}$ & $>4 \mathrm{UPU} / \mathrm{m}^{2}$ \\
\hline PBA & $\begin{array}{l}\text { Percentange of built-up } \\
\text { area }\end{array}$ & $\%$ & $<3 \%$ & $>10 \%$ \\
\hline DIS & $\begin{array}{l}\text { Dispersion of built-up } \\
\text { area }\end{array}$ & $\begin{array}{l}\text { UPU per } \mathrm{m}^{2} \text { of built- } \\
\text { up area }\end{array}$ & $<42.5 \mathrm{UPU} / \mathrm{m}^{2}$ & $\begin{array}{l}>45.5 \\
\mathrm{UPU} / \mathrm{m}^{2}\end{array}$ \\
\hline LUP & Land uptake per person & $\begin{array}{l}\mathrm{m}^{2} \text { per inhabitant or } \\
\text { job }\end{array}$ & $\begin{array}{l}<111 \mathrm{~m}^{2} \text { per } \\
\text { inhabitant }\end{array}$ & $\begin{array}{l}>222 \mathrm{~m}^{2} \text { per } \\
\text { inhabitant or } \\
\text { jobs }\end{array}$ \\
\hline UD & Utilisation density & $\begin{array}{l}\text { Inhabitant and job per } \\
\mathrm{km}^{2} \text { of built-up area }\end{array}$ & $\begin{array}{l}<4500 \text { inhabitant } \\
\text { and jobs per km² }\end{array}$ & $\begin{array}{l}>9000 \\
\text { inhabitants } \\
\mathrm{km}^{2}\end{array}$ \\
\hline UP & Urban permeation & $\begin{array}{l}\text { UPU per } \mathrm{m}^{2} \text { of } \\
\text { landscape }\end{array}$ & $<2 \mathrm{UPU} / \mathrm{m}^{2}$ & $>4 \mathrm{UPU} / \mathrm{m}$ \\
\hline
\end{tabular}

\subsection{International Village- Measurement of urban sprawl}

Tab. 6 Mesurement of urban sprawl

\begin{tabular}{|l|}
\hline \multicolumn{1}{|c|}{ Percentage of built-up area $($ PBA $)$} \\
\hline $\mathrm{PBA}=$ Built-up area / Landscape $\quad(1)$ \\
\hline $\mathrm{PBA}=2.8 \mathrm{ha} / 6.3 \mathrm{ha}=0.444 \times 100=44.4 \%$ (High level) \\
\hline Degree of urban dispersion $($ DIS $)$ \\
\hline $\mathrm{DIS}=$ Horizon of perception HP $(\mathrm{axb}) /$ Built-up area $\quad(2)$ \\
\hline $\mathrm{DIS}=0.120 / 2.8=42.85 \mathrm{UPU} / \mathrm{m}^{2}$ \\
\hline Land uptake per person $($ LUP $)$ \\
\hline $\mathrm{LUP}=$ Built-up area $/$ Number of inhabitant \\
\hline $\mathrm{LUP}=2.8 / 448=625 \mathrm{~m}^{2}$ per inhabitant $($ High level) \\
\hline Urban premeation $(\boldsymbol{U P})$ \\
\hline $\mathrm{UP}=\mathrm{PBA} \times \mathrm{DIS}$ \\
\hline $\mathrm{UP}=44.4 \times 42.85=19.02 \mathrm{UPU} / \mathrm{m}^{2}$ (High level) \\
\hline
\end{tabular}



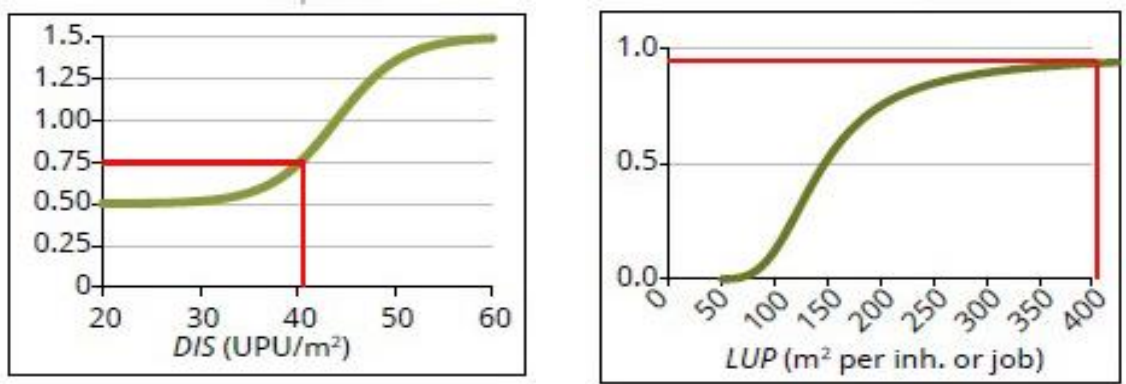

Fig. 10 DIS and LUP diagram

Tab. 7 Weighted urban proliferation

\begin{tabular}{|l|}
\hline Weighted urban proliferation $($ WUP) \\
\hline $\mathrm{WUP}=\mathrm{UP} \times \mathrm{w} 1$ (DIS) $\times \mathrm{w} 2(\mathrm{LUP})$ \\
\hline $\mathrm{WUP}=19.02 \times 0.75 \times 0.9=12.83 \mathrm{UP} / \mathrm{m}^{2} \quad$ (High level) \\
\hline
\end{tabular}

\subsection{Neighborhood Cherry- Measurement of urban sprawl}

Tab. 8 Mesaurment urban sprawl II

\begin{tabular}{|l|}
\hline \multicolumn{1}{|c|}{ Percentage of built-up area $(\boldsymbol{P B A})$} \\
\hline $\mathrm{PBA}=\mathrm{Built}-\mathrm{up}$ area $/$ Landscape $\quad(1)$ \\
\hline $\mathrm{PBA}=2.6 \mathrm{ha} / 9.3 \mathrm{ha}=27.95 \%(\mathrm{High}$ level $)$ \\
\hline Degree of urban dispersion $($ DIS $)$ \\
\hline $\mathrm{DIS}=\mathrm{HP}(\mathrm{axb}) /$ Built-up area $\quad(2)$ \\
\hline $\mathrm{DIS}=0.155 / 2.6=59.61 \mathrm{UPU} / \mathrm{m}^{2}($ High level $)$ \\
\hline Land uptake per person $(\boldsymbol{L U P})$ \\
\hline $\mathrm{LUP}=\mathrm{Built}-\mathrm{up}$ area $/ \mathrm{Number}$ of inhabitant \\
\hline $\mathrm{LUP}=2.6 / 520=500 \mathrm{~m}^{2}$ per inhabitant $($ High level $)$ \\
\hline Urban premeation $(\boldsymbol{U P})$ \\
\hline $\mathrm{UP}=\mathrm{PBA} \times \mathrm{DIS}$ \\
\hline $\mathrm{UP}=27.95 \times 59.61=16.66 \mathrm{UPU} / \mathrm{m}^{2}($ High level $)$ \\
\hline
\end{tabular}



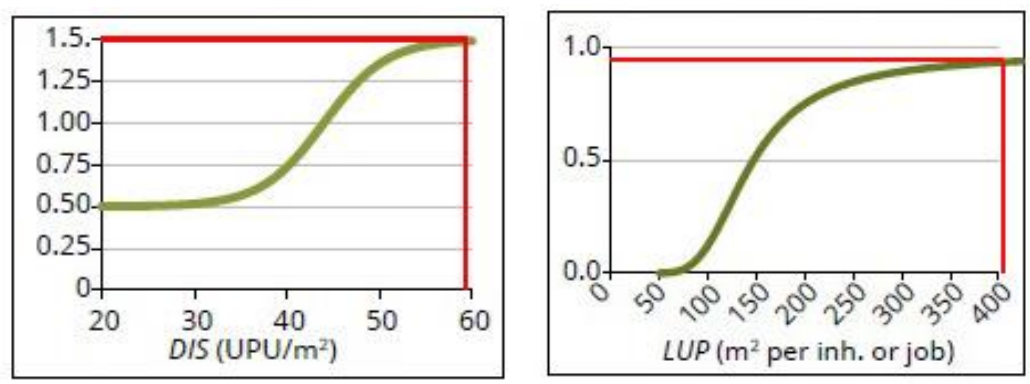

Fig. 11 DIS and LUP diagram

Tab. 9 Weighted urban proliferation

\begin{tabular}{|l|}
\hline Weighted urban proliferation $($ WUP) \\
\hline $\mathrm{WUP}=\mathrm{UP} \times \mathrm{w} 1$ (DIS) $\times \mathrm{w} 2(\mathrm{LUP})$ \\
\hline $\mathrm{WUP}=16.66 \times 1.5 \times 0.9=22.49 \mathrm{UP} / \mathrm{m}^{2}$ (High level) \\
\hline
\end{tabular}

\section{Swiss Village- Measurement of urban sprawl}

Tab. 10 Mesaurement of urban sprawl

\begin{tabular}{|l|}
\hline \multicolumn{1}{|c|}{ Percentage of built-up area $(\boldsymbol{P B A})$} \\
\hline $\mathrm{PBA}=$ Built-up area/ Landscape $\quad(1)$ \\
\hline $\mathrm{PBA}=0.8 \mathrm{ha} / 2.3 \mathrm{ha}=34.78 \%($ High level $)$ \\
\hline Degree of urban dispersion $($ DIS $)$ \\
\hline $\mathrm{DIS}=\mathrm{HP}(\mathrm{axb}) /$ Built-up area $\quad(2)$ \\
\hline $\mathrm{DIS}=0.25 / 0.8=31.25 \mathrm{UPU} / \mathrm{m}^{2}$ \\
\hline Land uptake per person $(\boldsymbol{L U P})$ \\
\hline $\mathrm{LUP}=$ Built-up area $/ \mathrm{Number}$ of inhabitant \\
\hline $\mathrm{LUP}=0.8 / 152=526 \mathrm{~m}^{2}$ per person $($ High level $)$ \\
\hline Urban premeation $(\boldsymbol{U P})$ \\
\hline $\mathrm{UP}=\mathrm{PBA} \times \mathrm{DIS}$ \\
\hline $\mathrm{UP}=34.78 \times 31.25=10.86 \mathrm{UPU} / \mathrm{m}^{2}$ (High level) \\
\hline
\end{tabular}
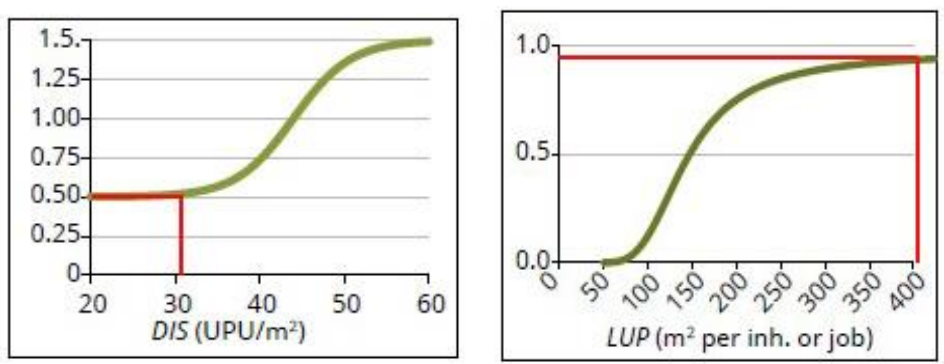

Fig. 12 DIS and LUP diagram 
Tab. 11 Weighted urban proliferatio

\begin{tabular}{|l|}
\hline Weighted urban proliferation (WUP) \\
\hline $\mathrm{WUP}=\mathrm{UP} \times \mathrm{w} 1(\mathrm{DIS}) \times \mathrm{w} 2(\mathrm{LUP})$ \\
\hline $\mathrm{WUP}=10.86 \times 0.5 \times 0.9=4.887 \mathrm{UP} / \mathrm{m}^{2}$ (High level) \\
\hline
\end{tabular}

\section{The impact of urban sprawl in cadastral zone Cagllavica}

\section{Enivornmental impact}

One of the most important factors that negatively impacts urban deprivation is the environment. Impact on the environment from poor urban sprawl includes some indicators such as impact on land use, mostly spending on agricultural land, then with the expansion of settlements there is a growing need for greater electricity consumption, as well as the extent of settlements away the urban area increases the need for greater use of cars, thereby increasing the level of air pollution and carbon dioxide emissions, as well as the noise level from large car use. With the expansion of settlements, there is a growing need for water consumption, especially in households, with the construction of individual homes with larger living space, and the price for communal tax payments increases. All of these indicators have been reviewed in this chapter, as well as the impact of the poor urban outlook in the Çagllavica neighborhood, including these indicators.

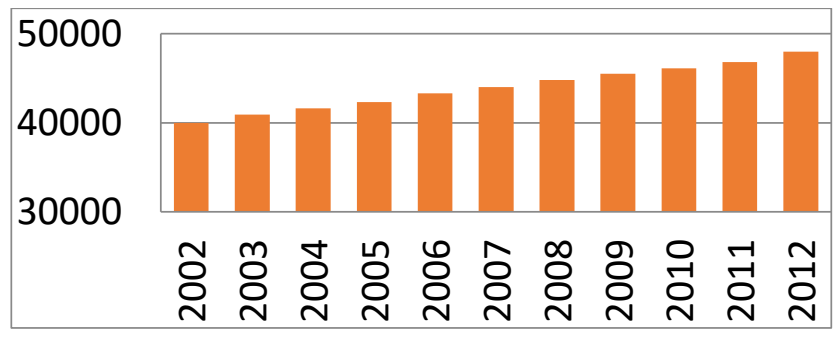

Fig. 13 Increased the built-up area in Kosova (Unit: ha)

Significant indicators in which urban wastes are affected is the greatest cost of electricity, as a result of building larger areas of living, which must be supplied with electricity. Electricity consumption in Kosovo has increased strongly since 2000 (2864 GWh) by 2007 (4582 GWh). The latest data show that consumption continues to grow to 5,420 GWh in 2009 (KOSTT's annual report for 2009). The main sources of domestic supply are the Kosovo A and Kosovo B lignite plants ( $97 \%$ of the local supply) and a small contribution (3\%) from the hydro power plants. Balance between supply and demand is supplemented by electricity imports (around 10\% a year).

\section{Economic impact}

Livelihoods affect larger communal prices, including property fees. According to the Immovable Property Tax Regulation of the Municipality of Prishtina (2011), where the areas and categories are allocated within the area, where based on the area in which the property is located, the tax per $\mathrm{m}^{2}$ is also determined. Z.k Çagllavica respectively the quarters in question, are part of the third zone defined under this regulation and are part of the first category of this zone. 


\section{Recommendations}

Concerns about losing open spaces, agricultural land productivity, traffic congestion, and increased public service cost should impact people's demand for more control over land development and construction. At the central level, it has great concern and increased funding to broaden the scope for protecting open spaces, environmental clean-ups, and new plans to protect agricultural land. The bad urban sprawl must be fought before it is too late. It is essential that urban planners stand against this stretch and create new innovative growth methods without expanding the city's physical boundaries.

Below are some recommendations, based on this research, which could help reduce the extent of urban misery.

Solutions to the Bad Urban Sprawl

- For developing countries, people living in the suburbs of the city are mostly rural immigrants who have come to town. The problem that needs to be addressed is, therefore, the creation of employment opportunities away from major metropolitan areas.

- Other solutions are the development or reuse of existing land within the city and the concentration of increased use of abandoned construction sites such as old schools, industrial land and parking spaces which can be reused by providing alternatives to land use virgin outside the city limits.

- The lack of a public transport system increases the dependence on private transport. One solution to this may be, the cars pay a high tariff for parking and use outside the urban area, thus driving these residents to return to the urban area. The municipality and the competent authorities are also the ones that can stop this phenomenon by giving high importance to the development of public transport.

Planned urban development for sustainable urbanization

One of the most important independent variables of global sustainability is urban development planning. In the broad, long-term, sustainable sense, urbanization should take the following indicators into a major concern:

- Urban planning process

- Sustainable urban environment components

- Definition and expected size of the city

\section{References}

1. Adaku, E. (2014). Urban Sprawl: A view from developing and developed countries. Ghana Institution of Managment and public administration, Ghana.

2. Bink, P., K. Mutafogu, J-P., Schweitzer, M. Kettunen, C. Twigger- Ross, Y. Kuipers. (2016). The health and social benefits of nature and biodiversity protection. Report from the European Commision (ENV.B.3/ETV/2014/0039), Institute for European Environmental Policy, London, Brussels.

3. Bhata, B. (210). Analysis of urban growth and sprawl from Remote. Springer- Verlag. Berlin, Heidlberg, pp.172.

4. Bosker, M., Walsh, G. (2003). Urban Growth and Decline in Europe. Tjalling C. Koompmans Research Institute, The Netherlands. 
5. Communities and Local Government. (2007). Best practice in urban extensions and new settlements. TCPA, London.

6. Couch, C., Leontidou, L., Petschel, G. (2007). Urban Sprawl in Europe: Landscapes, Land-use. Blackwell Publishers, Oxfor.

7. Degorska, B. (2010). Transformation of Rural areas into urban areas within the warsaw metropolitan area in the early $21^{\text {st }}$ centuries. IGU conference, Warsaw, Poland.

8. Dieleman, F., Wegner, M.(2009). Compact City and Urban Sprawl. Built Environment, Vol. 30, No.4.

9. Duranton, G., Turner, M. (2008). Urban Growth and Transportation. University of Toronto, Toronto.

10. European Environment Agency and Federal Office for the Environment. (2016). Urban Sprawl in Europe. In Joint EEA-FOEN report, No 11/2016. Publication office of the European Union, Luxembourg.

11. European Environment Agency. (2015). Urban Sustainability Issues- What is a ResourceEfficient City. EEA technical report, No 23/2015. Publications office of the European Union, Luxembourg.

12. Ferrer, J., Rinaldi, D. (2017). Key Challengs and Opportunities for Cites and Regions. European Union, Brussels.

13. Friere, M. (2006). Urban Planning: Challenges in Developing Countries. International congress on human development, Madrid.

14. Farrell, K. (2017). The Radio Urban Growth Triad: A new conceptual framework for examining the urban transition in developing countries. MDPI, Stockholm, Sweden.

15. Friedmann, J.,(1993). Modular cities. beyond the rural-urban divide. Department of Urban Planning, School of Public Policy and Social Research, UCLA.

16. Global Environment Facility. (2016). Sustainable Land Managment and its Relationships to Global Envitonmental Benefits and food security. Gef Council Meeting.

17. Gales, P. (1998). Regulations and Governance in European Cities. Joint Editors and Blackwell Publishers, Oxford.

18. Gomez, M., Hortas, M. (2014). The causes of urban sprawl in Spanish urban. GenGovernance and Economics research network. Marrë në: http://www.webs.uvigo.es/infogen.

19. Gurin, D. (2003). Understanding Sprawl. The David Suzuki Fundation. Vancouver, Canada.

20. Gallopeni, B. (2015, Shtator). Rural Urban Migration in Kosovo. University for Business and Technology, UBT. Prishtinë, Vol.6, No.9(1).

21. Gallopeni, B. (2016). Socio- Urban Developements in Kosovo study case Prishtina. Marrë në: http://www.Researchgate.net/Publication/303838862.

22. GAP, MEMO. (2017). Shkaqet e ndotjes së ajrit në Prishtinë. Prishtinë.

23. Glaeser, E., Kahn, M.(2003). Sprawl and Urban Growth. Harvard Institute of Economic Research discussion paper. 